\title{
The Effect of Temperature, Salinity and Nitrogen Products on Food Consumption of Pink Shrimp Farfantepenaeus paulensis
}

\author{
Wilson Wasielesky Jr. ${ }^{1 *}$, Adalto Bianchini ${ }^{2}$, Cecilia Castaño Sanchez ${ }^{1}$ and Luis Henrique \\ Poersch $^{1}$ \\ ${ }^{I}$ Fundação Universidade Federal do Rio Grande; Departamento de Oceanografia; Laboratório de Maricultura \\ (EMA/FURG); C. P. 474; 96201-900; Rio Grande - RS - Brasil. ${ }^{2}$ Fundação Universidade Federal do Rio Grande; \\ Departamento de Ciências Fisiológicas; Laboratório de Zoofisiologia; Rio Grande - RS - Brasil
}

\begin{abstract}
Studies were carried out to investigate the effect of temperature, salinity, ammonia, nitrite and nitrate on food consumption of pink shrimp Farfantepenaeus paulensis. Juveniles $(0.2-0.4 \mathrm{~g})$ were acclimated for 15 days in seawater with different temperatures, salinities and concentrations of ammonia, nitrite and nitrate. After the acclimation period, 20 shrimps per treatment were individualized in order to have their ration intake analyzed through the amount of ration offered and left over within a 24-hour period. Mean food consumption presented significant alterations $(P<0.05)$ for the tested temperatures and nitrite concentrations, whereas for the salinity, ammonia and nitrate treatments, shrimp presented no alteration on food intake $(P>0.05)$. According to the results obtained, temperature and nitrite affected $\underline{F}$. paulensis food consumption. On the other hand, variables as salinity, ammonia and nitrate did not affect shrimp appetite. However, the possibility of this to happen over long periods, prejudicing the species culture in captivity, reinforced the necessity of regular water quality management.
\end{abstract}

Key words: Culture, food consumption, shrimp, water quality

\section{INTRODUCTION}

The pink shrimp Farfantepenaeus paulensis is a commercially important species captured in southern Brazil (Valentini et al., 1991). The ability of such organism to thrive in temperatures lower than those normally tolerated by other penaeid shrimps casts a great interest in the species in regard to its culture in southernmost Brazil (Wasielesky, 1999).

Physical-chemical parameters of water affect food consumption of reared shrimp (Nunes, 1995), what may reduce growth rates and final cultured biomass within a pond. Several authors studied how variations of water quality influences shrimp behavior. (Marques and Andreatta, 1998) reported that alterations of salinity might influence $F$. paulensis consumption of ration. (Miranda, 1997) and (Santos et al., 2000) noticed an inhibitory effect on predation activities of $F$. paulensis when exposed to closed environments contaminated with ammonia and heavy metals, respectively. (Robertson et al., 1993) registered lower growth of Litopenaeus vannamei in high salinities, with reduction in food consumption, whereas (Wyban et al., 1995) working with the same species

* Author for correspondence 
registered significant changes in food intake and food conversion rates for lower temperatures. (Wasielesky 1999; 2000) reported significant variations on the growth of $F$. paulensis juveniles as a function of different physical-chemical parameters of water (i.e. temperature, and salinity), mainly due to changes of respiratory and excretory metabolism.

Nowadays, as a way to reduce feeding management expenses and keep acceptable pond water and bottom quality, even spending more with personnel, most shrimp farms are just using feed trays instead of broadcasting the ration through the entire grow-out pond guided by feeding tables. However, on both feeding schemes it is fundamental to have knowledge of how water quality influences food consumption (Marques and Andreatta, 1998).

\section{MATERIALS AND METHODS}

Shrimps used in the experiment came from EMA/FURG hatchery, according to the methodology cited by Marchiori (1996) and Cavalli et al. (1997), which comprises the capture of wild broodstock, induction to maturation, spawning, larviculture and nursery of post-larvae. Post-larvae kept in a 12,000 L tank for 45 days (average drained weight between 0.2 and $0.4 \mathrm{~g}$ ) were acclimatized to the environmental test conditions in 15 days. For this, juveniles of $F$. paulensis $(\mathrm{n}=25$ per treatment) were maintained in several $100 \mathrm{~L}$ polyethylene tanks with different salinities, temperatures, and concentrations of ammonia, nitrite, and nitrate (Table I), which were renewed at $70 \%$ daily rate. The concentrations of nitrogen compounds were defined on function of the species safe levels cited by Ostrensky and Wasielesky (1995), Castaño (1997) and Sachisida (1997), whereas the salinities and temperatures proposed for the tests were based on the work of Wasielesky (1999). During the acclimatization period, shrimps were fed ad libitum with fresh food (fish and crab) and ration $\left(\mathrm{Sibra}^{\circledR}\right.$ ) and submitted to photoperiod of $12 \mathrm{D} / 12 \mathrm{~L}$. Prior to the test, 20 shrimps per treatment were individually kept in $1 \mathrm{~L}$ beakers for 24 hours and fed ad libitum with the same ration. The food consumption test was then carried out when the experimental water (same acclimatization concentrations) of each beaker was totally renewed and pre-weighed ration was provided. Data from individuals that molted within the 24-hour test period were not taken into account. Afterwards, shrimps were removed from beakers and drained weighted. The experimental means were siphoned and filtered through a $30 \mu$ mesh, which was rinsed for the elimination of feces. The retained ration was scraped and placed on aluminum foil for dehydration at $60^{\circ} \mathrm{C}$, until it reached constant weight. Food consumption of dry matter was based on the difference between the weights of ration provided and left over, taking into account the blank test (which considered the initial percentage of ration humidity, solubility of some nutrients, and losses in the process of siphoning and rinsing). The equation for the calculus of dry matter consumption was:

$$
\mathrm{DMC}=\frac{\left[\left(\mathrm{R}_{\mathrm{O}} \times \underline{x}_{\left.\left.0.951)-\mathrm{R}_{\mathrm{D}}\right)\right] \times 0.916}\right.\right.}{\text { shrimp weight }}
$$

where: $\mathrm{DMC}=$ dry matter consumption ( $\mathrm{g}$ of dry matter/g of shrimp/day); $\mathrm{R}_{\mathrm{O}}=$ weight of ration offered $(\mathrm{g}) ; 0.951=$ percentage of initial dry matter of ration; $\mathrm{R}_{\mathrm{D}}=$ weight of ration dried $(\mathrm{g}) ; 0.916=$ percentage of dry matter after the blank test (methodology applied without shrimp).

The mean dry matter consumption obtained in each treatment was submitted to variance analysis (ANOVA), taking into account the necessary premises, and whenever significant differences $(\mathrm{P}<0,05)$ found, the Tukey test was applied.

\section{RESULTS}

Food consumption of dry matter was dependent of temperature and varied from 0.32 to $0.71 \mathrm{~g} / \mathrm{g}$ of shrimp/day. At $16^{\circ} \mathrm{C}$, food consumption was significantly lower $(\mathrm{P}<0.05)$ than other tested temperatures. In contrast, higher food consumption rate was observed at 26,29 and $32^{\circ} \mathrm{C}$ (Fig. 1). In relation to salinity, food consumption varied from 0.45 and $0.55 \mathrm{~g} / \mathrm{g}$ of shrimp/day, without statistical difference $(\mathrm{P}>0.05)$ among treatments (Fig.2). 
Table 1 - Different treatments to analyse $F$. paulensis food consumption.

\begin{tabular}{llll}
\hline Parameter & Treatments & Temperature $\left({ }^{\circ} \mathrm{C}\right)$ & Salinity $(\mathrm{ppt})$ \\
\hline Salinity & $2 ; 4 ; 6 ; 12 ; 18 ; 24 ; 30$ and 36 & 25 & - \\
Temperature $\left({ }^{\circ} \mathrm{C}\right)$ & $16 ; 20 ; 23 ; 26 ; 29$ and 32 & - & 23 \\
Ammonia $(\mathrm{mg} / \mathrm{L} \mathrm{N}-\mathrm{AT})$ & Control; 0,$91 ; 3,65$ and 7,30 & 25 & 23 \\
Nitrite $\left(\mathrm{mg} / \mathrm{L} \mathrm{N}-\mathrm{NO}_{2}{ }^{-}\right)$ & Control; $2,04,10,2$ and 20,4 & 25 & 23 \\
Nitrate $\left(\mathrm{mg} / \mathrm{L} \mathrm{N}-\mathrm{NO}_{3}{ }^{-}\right)$ & Control, $64,6,323$ and 646 & 25 & 23 \\
\hline
\end{tabular}

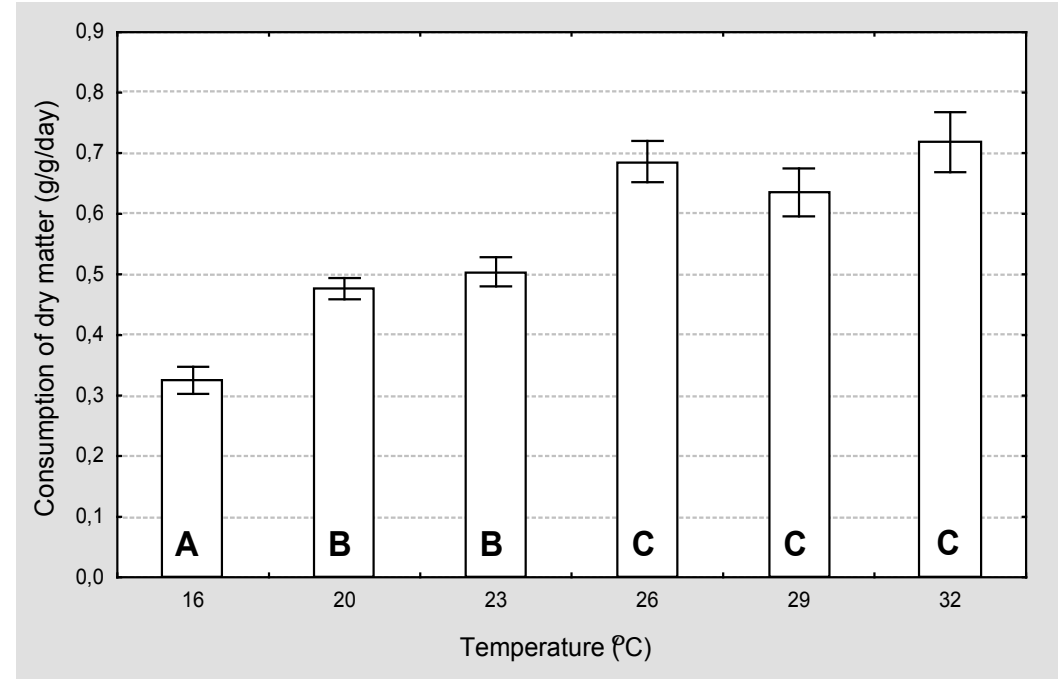

Figure 1. Consumption of dry matter by pink shrimp $F$. paulensis juveniles at different temperatures. Data represent means \pm SD. Same letters indicate similar statistical means $(\mathrm{P}>0.05)$.

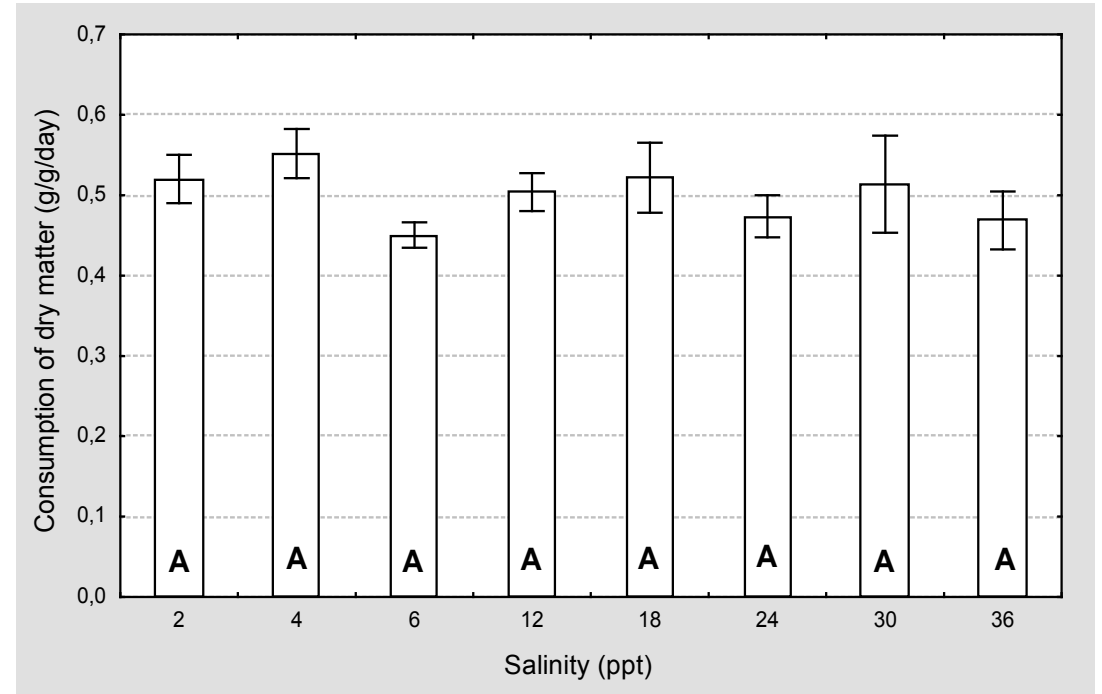

Figure 2. Consumption of dry matter by pink shrimp $F$. paulensis juveniles at different salinities. Data represent means $\pm \mathrm{SD}$. Same letters indicate similar statistical means $(\mathrm{P}>0.05)$. 


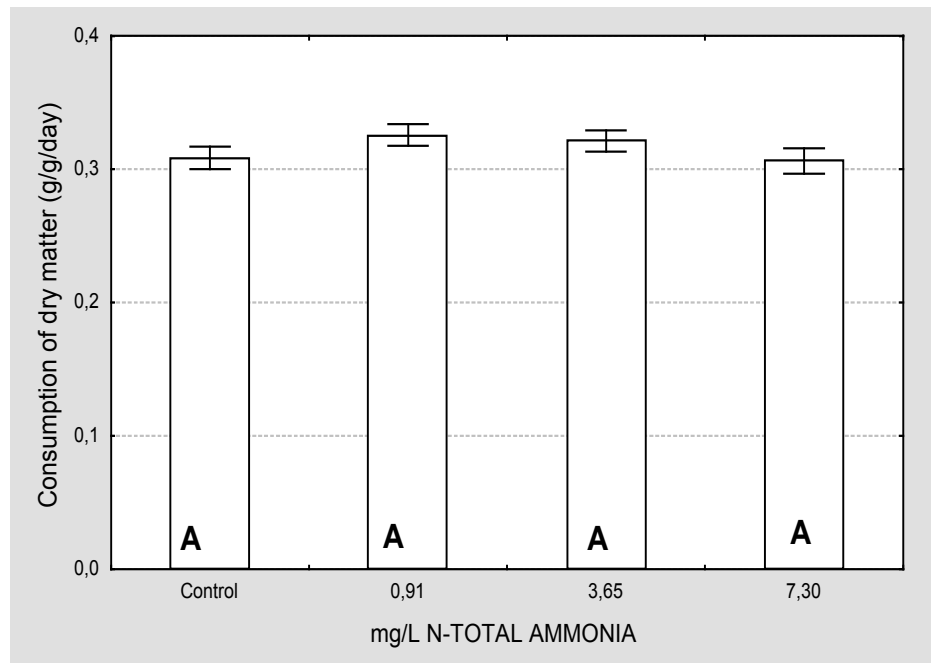

Figure 3. Consumption of dry matter by pink shrimp $F$. paulensis juveniles exposed to different concentrations of ammonia. Data represent means \pm SD. Same letters indicate similar statistical means $(\mathrm{P}>0.05)$.

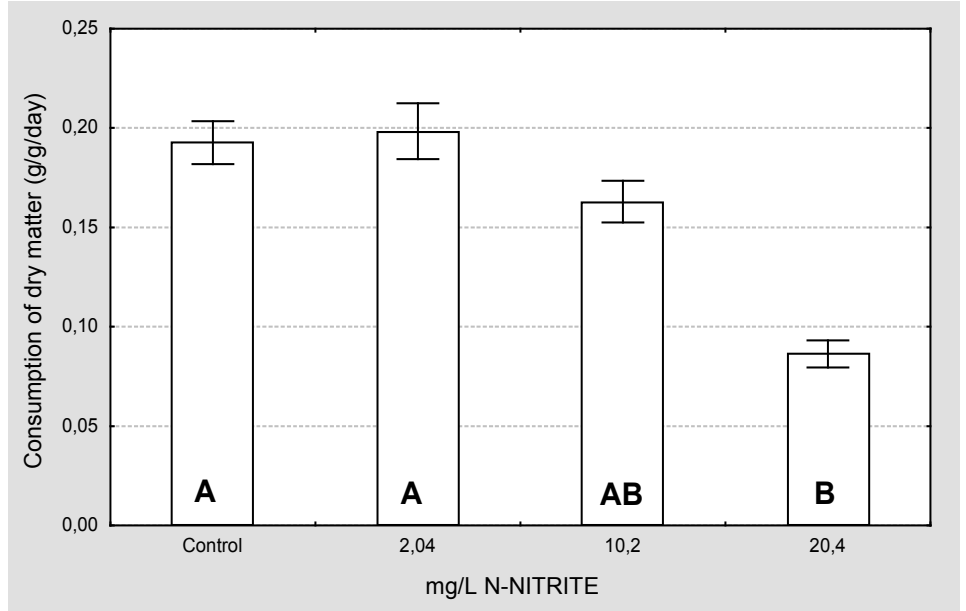

Figure 4. Consumption of dry matter by pink shrimp F. paulensis juveniles exposed to different concentrations of nitrite. Data represent means \pm SD. Same letters indicate similar statistical means $(\mathrm{P}>0.05)$. 


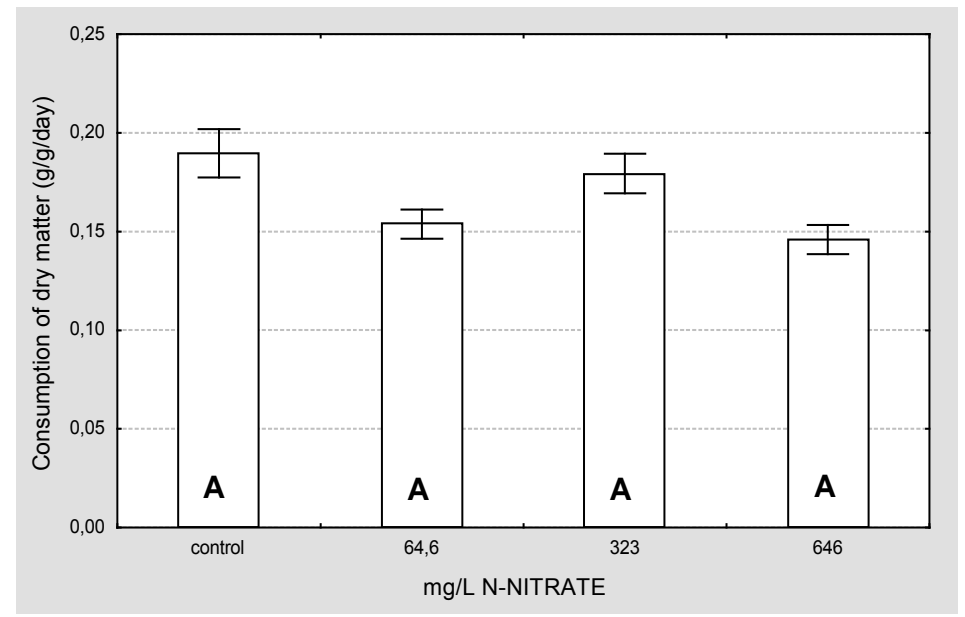

Figure 5. Consumption of dry matter by pink shrimp $F$. paulensis juveniles exposed to different concentrations of nitrate. Data represent means \pm SD. Same letters indicate similar statistical means $(\mathrm{P}>0.05)$.

Ammonia and nitrate also did not significantly affect food consumption of $F$. paulensis juveniles. In these cases, consumption ranged from 0.30 and $0.34 \mathrm{~g} / \mathrm{g} /$ day (Fig. 3) for ammonia and 0.14 and $0.18 \mathrm{~g} / \mathrm{g} /$ day for nitrate (Fig. 5). Higher levels of nitrite, on the other hand, showed significant variation from the control, diminishing $F$. paulensis appetite above $10.2 \mathrm{~N}^{-\mathrm{NO}_{2}}{ }^{-} \mathrm{mg} / \mathrm{L}$. For the latter experiment, consumption of dry matter varied from 0.07 to $0.19 \mathrm{~g} / \mathrm{g} /$ day (Fig. 4).

\section{DISCUSSION}

Within the range of tested salinities (2 to 36 ), food consumption of $F$. paulensis was not significantly affected. However, Marques and Andreatta (1998) reported significant differences for $F$. paulensis consumption of ration at low salinity (5 ppt). The difference between both results could be due to the different methodologies applied, since the other authors accomplished a 30-day experiment, in which food consumption was analyzed as function of the amount of ration offered through the period. From both works, it could be concluded that within the tolerance range for the species, the effect of salinity on food consumption was not expressive. Vinod et al. (1996), reported lower food consumption and growth of Farfantepenaeus merguiensis in high salinity (45 ppt).

Temperature, on the other hand, is a variable, which induces several expressive effects on shrimps. Wyban et al. (1995), working with
Litopenaeus vannamei in the temperatures of 23 , 27 and $30^{\circ} \mathrm{C}$, verified that the higher temperatures increased shrimp appetite. Similar effect was found for $F$. paulensis, with two-fold increase on food consumption from 16 to above $26^{\circ} \mathrm{C}$. In fact, the levels of food consumption stabilized from 26 up to $32^{\circ} \mathrm{C}$ (maximum tolerance limit), instead of increasing directly with temperature. As described by Wasielesky (1999 and 2000), temperature also significantly affected growth and metabolic rates of $F$. paulensis, which influenced its food intake

Nitrogen compounds, as a general rule, cause significant effects on marine shrimps. Ostrensky and Wasielesky (1995) and Wasielesky et al. (1994) described the adverse effect of these compounds on survival and growth of $F$. paulensis, respectively. In the present study, tested concentrations of ammonia and nitrate did not affect the consumption of dry matter by the shrimp after 15 days of exposure. Nevertheless, no effect on food consumption here could be explained by the short period of exposure. Miranda (1997) analyzed the effect of ammonia on the predatory activity of $F$. paulensis juveniles and observed lower intake of brine-shrimp (Artemia sp.) nauplii in concentrations of 6.27 and $13.33 \mathrm{mg} / \mathrm{L} \mathrm{N}$-TA, after 75 days of exposure to the toxic.

Contrary to the other nitrogen compounds, nitrite presented significant adverse effect on $F$. paulensis food consumption rates, even within a 15-day exposition. At the safe level $(10.2 \mathrm{mg} / \mathrm{L} \mathrm{N}$ $\mathrm{NO}_{2}{ }^{-}$), consumption was about $15 \%$ lower than that registered for the control, and up to $20.4 \mathrm{mg} / \mathrm{L}$ 
$\mathrm{N}-\mathrm{NO}_{2}{ }^{-}$, the reduction was of $50 \%$. The effect of nitrite on food consumption may be associated with an action of the nitrite over the respiratory pigments, impairing the binding and carrying capacity of oxygen by hemolymph (Tahon et al., 1988). Such effects certainly would reduce the aerobic metabolism, leading to alterations on normal food consumption. This hypothesis is based on the fact that $F$. paulensis has its average oxygen consumption rate significantly reduced when exposed to nitrite concentrations of $1,5,10$ and $20 \mathrm{mg} / \mathrm{L} \mathrm{N}^{-\mathrm{NO}_{2}}{ }^{-}$(Wasielesky et al., 1998).

Wong et al. (1993) related the crucial importance of food consumption on growth and survival of Metapenaeus ensis. Under adverse conditions, such as pollutants, organisms spend considerable amount of energy from feeding into homeostasis. Therefore, lower food intake by on-growing organisms, lower the growth rate, which, on a commercial scale could be risks for the crops.

According to the results obtained in the present study, it could be concluded that temperature and certain levels of nitrite in the water affected $F$. paulensis food consumption. On the other hand, within short periods, water variables as salinity, and some concentrations of ammonia and nitrate did not affect $F$. paulensis appetite. However, the possibility of this to happen over long periods, prejudicing the species culture in captivity, reinforces the necessity of regular water quality analyses and management.

\section{ACKNOWLEDGMENTS}

The authors gratefully thank to Fishery Pole (Pólo de Modernização Tecnológica - Litoral Sul), which belongs to State of Rio Grande do Sul Secretary of Science and Technology (Secretaria de Ciência e Tecnologia do Estado do Rio Grande do Sul - SCT - RS) for the financial support in the execution of this work.

\section{RESUMO}

Nos cultivos de organismos aquáticos, a manutenção da qualidade da água é fundamental para o sucesso da atividade, tendo em vista que variações nos parâmetros físico-químicos implicam em alterações metabólicas. O consumo de alimento por parte dos camarões pode ser afetado por estas variações, o que interfere nas taxas de crescimento e conseqüentemente na biomassa final produzida. $\mathrm{O}$ objetivo deste trabalho foi investigar o efeito da temperatura, salinidade, amônia, nitrito e nitrato sobre o consumo alimentar do camarão-rosa Farfantepenaeus paulensis. Desta forma, juvenis $(0,2-0,4 \mathrm{~g})$ foram aclimatados por 15 dias em água do mar com diferentes temperaturas, salinidades, concentrações de amônia, nitrito e nitrato. Após o período de aclimatação, 20 camarões de cada tratamento foram individualmente analisados para observar a relação entre a quantidade de alimento oferecido e a quantidade de alimento ingerido, em um período de 24 horas. O consumo médio apresentou alterações significativas $(p<0,05)$ nos testes de temperatura e de nitrito, enquanto que nos tratamentos de amônia, nitrato e salinidade, não detectou-se alterações no consumo alimentar $(\mathrm{p}>0,05)$. De acordo com os resultados obtidos, conclui-se que a temperatura e o nitrito afetam o consumo alimentar de F. paulensis. Por outro lado, para os intervalos testados nos tratamentos de salinidade, amônia e nitrato, a ingestão de alimento dos camarões não foi afetada. Cabe ressaltar que longos períodos de exposição, a estas condições, podem afetar as espécies cultivadas, reforçando a importância do manejo na manutenção da qualidade de água.

\section{REFERENCES}

Castaño, C. S. (1997), Toxicidade aguda do nitrito sobre o camarão rosa Penaeus paulensis, cultivados em diferentes salinidades. Monografia de graduação, curso de Oceanologia, Fundação Universidade Federal do Rio Grande (FURG), Rio Grande, RS, Brasil.

Cavalli, R. O.; Scardua, M. and Wasielesky, W. J. (1997), Reproductive performance of different-sized wild and pond-reared Penaeus paulensis females. J. World Aquac. Soc., 28 : (3), 260-267.

Marchiori, M. A. (1996), Guia Ilustrado de Maturação e Larvicultura do Camarão Rosa Penaeus paulensis Pérez-Farafante, 1967. Rio Grande : FURG. 79 pp.

Marques, L. C. and Andreatta, E. R. (1998), Efeito da salinidade sobre o consumo de ração, crescimento e sobrevivência de juvenis do camarão rosa Penaeus paulensis (Pérez-Farfante, 1967). In: Anais... Aquicultura Brasil. Recife, 2, 804 pp. 
Miranda, K. C. F. (1997), Efeito da amônia na sobrevivência e crescimento da camarão rosa Penaeus paulensis Péres-Farfante, 1967 (Crustacea:Decapoda), Tese de mestrado em Oceanografia Biológica, Fundação Universidade Federal do Rio Grande (FURG), Rio Grande, RS, Brasil.

Nunes, A. J. P. (1995), Feeding dynamics of Southern brown shrimp Penaeus subtilis (Pérez-Farfante, 1967) (Crustacea, Penaeidae) under semi-intensive culture in NE Brazil. Tese de Mestrado em Aquacultura. Memorial University of Newfoundland, Newfoundland, Canadá.

Ostrensky, A. and Wasielesky, W. J. (1995), Acute toxicity of ammonia to various life stages of the São Paulo shrimp Penaeus paulensis Pérez-Farfante, 1967. Aquac., 132, 339-347.

Robertson, L.; Lawrence, A. L. and Castille, F. (1993), Interaction and salinity and feed protein levels on growth of Penaeus vannamei. J. Applied Aquac., 2 : (1), 43-54.

Sachisida, A. (1997), Efeito do nitrato no crescimento de juvenis do camarão rosa Penaeus paulensis (Crustacea: Decapoda) Monografia de graduação, curso de Oceanologia, Fundação Universidade Federal do Rio Grande (FURG), Rio Grande, RS.

Santos, M. H. S.; Cunha, N. T. and Bianchini, A. (2000), Effects of copper and zinc on growth, feeding and oxygen consumption of Farfantepenaeus paulensis post larvae (Decapoda: Penaeidae), J. Exp. Mar. Biol. Ecol., 247, 233-242.

Tahon, J. P.;Van Hoof, D.; Vinckier, C.; Witters, R.; De Ley, M. and Lonhe, R. (1988), The reaction of nitrite with the haemocyanin of Astacus leptodactylus. Biochem. J., 249, 891- 896.

Valentini, H.; D'incao, F. Rodrigues, L. F.; Rebelo Neto, J. E. and Rahn, E. (1991), Análise da pesca do camarão rosa (Penaeus paulensis e Penaeus brasiliensis) nas regiões sudeste e sul do Brasil. Atlânt., 13 (1), 143-157.

Vinod, K.; Bhat, U. G. and Neelakantan, B. (1996), Effect of salinity on food intake, growth and conversion efficiencies of juvenile Penaeus merguiensis (Man), Environ. Ecol., 14 (1),74-75.

Wasielesky, W. J.; Marchiori, M. A. and Santos, M. H. S. (1994), Efeito da amônia no crescimento de pós-larvas do camarão rosa, Penaeus paulensis, PÉREZ- FARFANTE, 1967 (Decapoda:Penaeidae), Nauplius, 2, 99-105.

Wasielesky, W. J.; Castaño, C. S.; Poersch, L. H. and Bianchini, A. (1998), Efeito do nitrito sobre o consumo de oxigênio de juvenis do camarão rosa Penaeus paulensis. In: XI Semana Nacional de Oceanografia, realizada de 18 à 24/10/98, em Rio Grande, RS, Brasil.
Wasielesky, W. J. (1999), Production of Marine Shrimp Penaeus paulensis in Southern Brazil: Culture in Alternative Structures. In: Oceanos: Fontes de Alimentos. Publication of Roberto Marinho Foundation, Gerdau, and CNPq, XV Jovem Cientista Award. pp. 53-106.

Wasielesky, W. J. (2000), Culture of pink shrimp Farfantepenaeus paulensis (Decapoda:Penaeidae) in Patos Lagoon estuary: effects of environmental parameters and management. Biological Oceanography Ph.D. thesis, Fundação Universidade Federal do Rio Grande, RS, Brazil.

Wong, C. K.; Chu, K. H.; Tang, K. W.; Tam, T. W. and Wong, L. J. (1993), Effects of chromium, copper and nickel on survival and feeding behaviour of Metapenaeus ensis larvae and postlarvae (Decapode:Penaeidae), Mar. Environ. Res., 36, 63-78.

Wyban, J.; Walsh, W. A. and Godin, D. M. (1995), Temperature effects on growth, feeding rate and feed conversion of the Pacific white shrimp (Penaeus vannamei), Aquac. 138 : (1/4), 267-279.

Received: April 02, 2001; Revised: June 26, 2001; Accepted: July 29, 2002. 